Erzincan Üniversitesi

Fen Bilimleri Enstitüsü Dergisi

2021, 14(3), 1006-1014

ISSN: 1307-9085, e-ISSN: 2149-4584

Araştırma Makalesi
Erzincan University

Journal of Science and Technology

2021, 14(3), 1006-1014

DOI: $10.18185 /$ erzifbed.981379

\title{
Determination of Egg Internal and External Quality Characteristics with Mathematical Formulas in Guinea Hens
}

\author{
Mehmet Hanifi AYSONDU ${ }^{1} \oplus$, Selçuk ÖZYÜREK ${ }^{2 *} \bullet$ \\ ${ }^{1}$ Malatya Turgut Özal Üniversitesi, Akçadağ Meslek Yüksekokulu, Laborant ve Veteriner Sağlık Programı, \\ Malatya / Türkiye \\ ${ }^{2}$ Erzincan Binali Yıldırım Üniversitesi, Çayırlı Meslek Yüksekokulu, Laborant ve Veteriner Sağlık Programı, \\ Erzincan / Türkiye
}

Geliş / Received: 22/06/2021, Kabul / Accepted: 12/10/2021

\begin{abstract}
This study was carried out to determine some internal and external quality characteristics of 378 eggs collected between March and July from 42-week-old Guinea Hens (Numidae meleagris) raised by the public in Erzincan province, using mathematical formulas. Egg external quality features include shape index 73\%, elongation 1.37, egg surface area $55.65 \mathrm{~cm}^{2}$, egg volume $40.39 \mathrm{~cm}^{3}$, shell thickness $0.28 \mathrm{~mm}$, shell weight $3.19 \mathrm{~g}$, number of pores-1 6686.05, number of pores-2 5156.10, number of pores- 35043.33 pieces, pore density-1 120.22 pore number $/ \mathrm{cm}^{2}$, pore density-2 92.62 pore number $/ \mathrm{cm}^{2}$, pore density-3 90.52 pore number $/ \mathrm{cm}^{2}$; The yolk weight and white weight of the egg were determined as $6.02 \mathrm{~g}$ and $30.89 \mathrm{~g}$, from the egg internal quality characteristics. As a result, in this study, yolk weight, shell weight and shell thickness values of egg internal and external quality characteristics calculated using mathematical formulas based on egg weight without spoiling the egg integrity were found to be lower than the values in some studies determined by measurement, while the white weight value was found to be higher.
\end{abstract}

Key words: Guinea fowl, Egg Weight, Shape Index, Shell Thickness and Weight, Egg Yolk and White Weight

\section{Beç Tavuklarında Matematiksel Formüller İle Yumurta İç ve Dış Kalite Özelliklerinin Belirlenmesi}

\section{$\ddot{O} \mathbf{z}$}

$\mathrm{Bu}$ çalışma, Erzincan ilinde halk elinde yetiştirilen 42 haftalık yaşta olan Beç Tavuklarından (Numidae meleagris) Mart-Temmuz ayları arasında toplanan 378 adet yumurtanın matematiksel formüller kullanılarak bazı iç ve dış kalite özelliklerinin belirlenmesi amacıyla yapılmıştır. Yumurta dış kalite özelliklerinden şekil indeksi $\%$ 73, elongasyon 1.37, yumurta yüzey alanı $55.65 \mathrm{~cm}^{2}$, yumurta hacmi $40.39 \mathrm{~cm}^{3}$, kabuk kalınlığ $0.28 \mathrm{~mm}$, kabuk ağırlığı 3.19 g, gözenek sayısı-1 6686.05 adet, gözenek sayısı-2 5156.10 adet, gözenek sayıs1-3 5043.33 adet, gözenek yoğunluğu-1 120.22 gözenek sayısı/cm², gözenek yoğunluğu-2 92.62 gözenek say1S1 $/ \mathrm{cm}^{2}$, gözenek yoğunluğu-3 90.52 gözenek sayısı/cm²; yumurta iç kalite özelliklerinden sarı ağırlığı 6.02 g ve ak ağırlı̆̆ 30.89 g olarak belirlenmiştir. Sonuç olarak bu çalışmada yumurta bütünlüğü bozulmadan yumurta ağırlığı baz alınarak matematiksel formüller kullanılarak hesaplanan yumurta iç ve diş kalite özelliklerinden sarı ağırlığı, kabuk ağırlığı ve kabuk kalınlığı değerleri ölçümle belirlenen bazı çalışmalardaki değerlerden düşük bulunurken ak ağırlığı değeri ise yüksek bulunmuştur.

Anahtar Kelimeler: Beç Tavuğu, Yumurta Ağırlığı, Şekil İndeksi, Kabuk Kalınlığı ve Ağırlığı, Yumurta Sarı ve Ak Ağırlı̆̆1

${ }^{*}$ Corresponding Author: sozyurek@erzincan.edu.tr 


\section{Introduction}

Guinea fowl, which is the native chicken of the African continent, (Smith, 1990) is in the Galliformes order of the Numididae subfamily of the Phasinidae family (Koch and Rossa, 1973; Austin et al., 1975; Demirsoy, 1992). The meat of guinea fowl, known as game and ornamental bird, has a pleasant aroma in terms of taste and flavor. Guinea fowl meat is rich in lean and essential unsaturated fatty acids (Petek, 2004).

Guinea fowls start to lay eggs at an average age of 26-32 weeks, usually in March or April, and laying can continue until October (Nwagu, 1997). It is important to determine the quality characteristics of the egg, which is the breeding material with its nutritive feature. Different criteria and methods are used to determine quality characteristics. It is used in some mathematical formulas developed to determine egg quality characteristics (Paganelli et al., 1974; Hoyt et al., 1979; Sotherland and Rahn, 1987; Rahn and Paganelli, 1988, Çopur Akpınar vd., 2017).

It is important to preserve the shell integrity of the eggs obtained in order to maintain the flock in poultry species produced in limited numbers. Mathematical formulas can be used to determine the quality characteristics of eggs obtained from these species. With the help of the formulas used to determine the quality characteristics, economic gain can be maintained for the breeder by protecting the integrity of the eggs without breaking them (Çopur Akpınar vd., 2017).

This study was carried out to determine some internal and external quality characteristics of 378 eggs collected from 42 weeks old Guinea fowl (Numidae meleagris) raised by the public in Erzincan between March and July, using mathematical formulas.

\section{Material and Method}

In the study, 378 eggs collected between March and July from 42-year-old Guinea hens raised in a private enterprise in the city center of Erzincan were used. After the eggs were numbered, they were weighed with an electronic scale sensitive to $0.01 \mathrm{mg}$ and the egg weight was determined as g. Egg internal and external quality characteristics were determined with the help of mathematical formulas without breaking the eggs whose weights were determined. In this context, the following formulas were used.

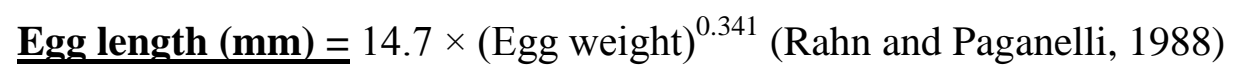

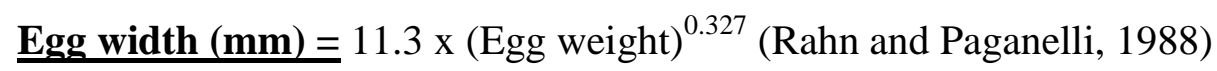

Shape Index $(\%)=($ Egg Width $/$ Egg Length $) \times 100($ Rahn and Paganelli, 1988 $)$

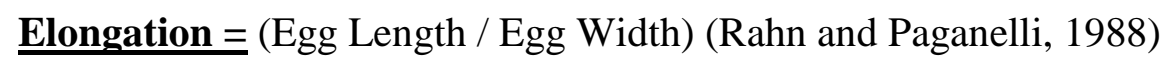

$\underline{\text { Egg surface area }(\mathbf{c m} 2)}=4.835 \times(\text { Egg Weight })^{0.662}($ Paganelli et al., 1974) 
$\underline{\text { Egg Volume }(\mathbf{c m} 3)}=(0.452+0.069$ Egg Length $/$ Egg Width $) \times\left(\right.$ Egg Length $\times$ Egg Width $\left.{ }^{2}\right)$ (Paganelli et al., 1974)

Shell weight $(\mathbf{g})=0.0524 \times(\text { Egg Weight })^{1.113}($ Rahn and Paganelli, 1989)

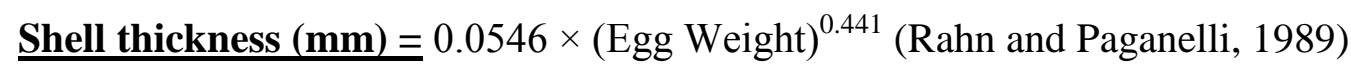

Number of Pores-1= $1041 \times(\text { Egg Weight })^{0.504}$ (Hoyt et al., 1979)

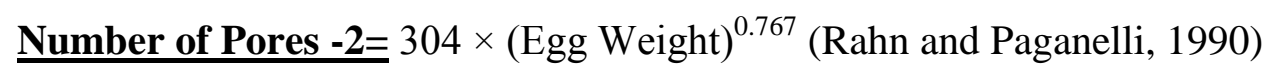

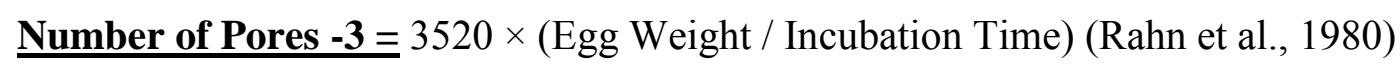

Pore Density $($ Pore/cm2) $=($ Pore Number / Egg Surface Area) $($ Paganelli et al., 1974)

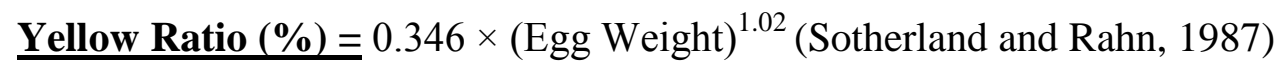

Egg Yolk Weight $($ g) $=($ Egg Weight $\times$ Yolk Ratio $) / 100$

White weight $(\mathbf{g})=$ Egg Weight $-($ Shell Weight + Yolk Weight) (Sarıca and Erensayın, 2009)

Whitening ratio $(\%)=($ White weight/ Egg Weight $) \times 100$

\subsection{Statistical Analysis}

SPPS 21. package program was used in the statistical evaluation of the data obtained in the study.

\section{Result and Discussion}

The results of egg length and width, shape index, elongation parameters of guinea fowl eggs based on egg weight are given in Table 1. Average egg weight was $40.10 \mathrm{~g}$, shape index was $73 \%$ and elongation was 1.37 .

Table 1. External quality characteristics of Guinea fowl eggs

\begin{tabular}{lcccc}
\hline Features & $\mathbf{n}$ & Minimum & Maximum & Average \\
\hline Egg weight $(\mathbf{g})$ & 378 & 30.10 & 49.01 & $40.10(2.95)$ \\
Egg length $(\mathbf{m m})$ & 378 & 46.94 & 55.42 & $51.73(1.31)$ \\
Egg width $(\mathbf{m m})$ & 378 & 34.40 & 40.35 & $37.76(0.92)$ \\
Shape index (\%) & 378 & 72.79 & 73.29 & $73.00(0.8)$ \\
Elongation & 378 & 1.36 & 1.37 & $1.37(0.00)$ \\
\hline
\end{tabular}

Shell characteristics of guinea fowl eggs are given in Table 2. It was determined that the shell thickness of guinea fowl eggs varied between 0.25 and $0.30 \mathrm{~mm}$, shell weight between 2.32 and $3.99 \mathrm{~g}$, egg surface area between 46.05 and $63.59 \mathrm{~cm} 2$, and egg volume between 30.34 and $49.33 \mathrm{~cm}^{3}$. 
Data on shell pore number and pore density in guinea fowl eggs are given in Table 3 . The pore number 1 , the pore number 2 and the pore number 3 values were calculated as 6686.05 , 5156.10 and 5043.33, respectively, pore density 1 , pore density 2 and pore number. density 3 values were found to be $120.22,92.62$ and 90.52 pores $/ \mathrm{cm}^{2}$, respectively.

Table 2. Shell characteristics of guinea fowl eggs

\begin{tabular}{lcccc}
\hline Features & n & Minimum & Maximum & Average \\
\hline Shell thickness $(\mathbf{m m})$ & 378 & 0.25 & 0.30 & $0.28(0.01)$ \\
Shell weight $(\mathbf{g})$ & 378 & 2.32 & 3.99 & $3.19(0.26)$ \\
Surface Area $(\mathbf{c m} 2)$ & 378 & 46.05 & 63.59 & $55.65(2.72)$ \\
Egg volume $(\mathbf{c m 3})$ & 378 & 30.34 & 49.33 & $40.39(2.96)$ \\
Surface/Volume ratio & 378 & 1.289 & 1.518 & 1.380 \\
\hline
\end{tabular}

Statistical descriptive data regarding the weights and ratios of yellow, white and bark, which are internal quality characteristics, are given in Table 4. Average yellow weight was $6.02 \mathrm{~g}$, white weight was $30.89 \mathrm{~g}$ and shell weight was $3.19 \mathrm{~g}$. It has been calculated that $14.94 \%$ of guinea fowl eggs consist of yellow, $77.11 \%$ white and $7.95 \%$ shell.

Table 3. Number of shell pores and pore density in guinea fowl eggs

\begin{tabular}{|c|c|c|c|c|}
\hline Features & $\mathbf{n}$ & Minimum & Maximum & Average \\
\hline Number of Pores 1 (pcs) & 378 & 5789.89 & 7401.94 & $6686.05(249.50)$ \\
\hline Pore density 1 (pore/cm²) & 378 & 116.41 & 125.73 & $120.22(1.42)$ \\
\hline Number of Pores 2 (pcs) & 378 & 4139.68 & 6016.01 & $5156.10(291.57)$ \\
\hline Pore density 2 (pore $\left./ \mathrm{cm}^{2}\right)$ & 378 & 89.89 & 94.61 & $92.62(0.73)$ \\
\hline Number of Pores 3 (pcs) & 378 & 3784.38 & 6161.01 & $5043.33(370.04)$ \\
\hline Pore density 3 (pore $/ \mathrm{cm}^{2}$ ) & 378 & 82.18 & 96.89 & $90.52(2.31)$ \\
\hline
\end{tabular}

Table 4. Internal quality characteristics of guinea fowl eggs

\begin{tabular}{lcccc}
\hline Features & $\mathbf{n}$ & Minimum & Maximum & Average \\
\hline Shell weight $(\mathbf{g})$ & 378 & 2.32 & 3.99 & $3.19(0.26)$ \\
yellow weight $(\mathbf{g})$ & 378 & 3.36 & 8.98 & $6.02(0.88)$ \\
Ak weight $(\mathbf{g})$ & 378 & 24.43 & 36.04 & $30.89(1.81)$ \\
Shell rate $(\boldsymbol{\%})$ & 378 & 7.70 & 8.13 & $7.95(0.07)$ \\
Yellow rate $(\%)$ & 378 & 11.15 & 18.33 & $14.94(1.12)$ \\
White percentage $(\boldsymbol{\%})$ & 378 & 73.54 & 81.15 & $77.11(1.19)$ \\
\hline
\end{tabular}




\section{Conclusion}

In this study carried out to determine guinea fowl egg quality, the weight of the eggs was found to be minimum $30.10 \mathrm{~g}$, maximum $49 \mathrm{~g}$ and average $40.10 \mathrm{~g}$. In some studies conducted in guinea pigs, the average egg weight was reported as $40 \mathrm{~g}$. (Vekic et al., 2019, Yamak vd., 2015; Alkan vd., 2013; Bernacki et al., 2013; Ivanova et al., 2020; Nickolova, 2009; Eleroğlu vd., 2016) and the results obtained in our study were similar. However, the average egg weight obtained in our study was lower than the values reported by Tebesi et al. (2012) (43.16 g); Dudusola (2010) (46.65 g); Nowaczewski et al. (2008)(55.3 g) and Song et al. (2000) (46.65 g), was higher than Oke et al. (2004) (29.1-38.4 g); Sing and Kumar (2008) (36.8 g); Obike et al. (2011) (37.67-37.91 g) and Gholipour et al. (2017) (36.21-39.22 g).

The average elongation value was 1.37 , and the shape index value was found to be $73 \%$ on average. The elongation value is similar to the value reported by Eleroğlu and Bircan (2019a) (1.37); It was found to be higher than the value reported by Eleroğlu and Bircan (2019b) (1.28). Eleroğlu and Bircan (2019a) found the shape index 73.1\%, Nowaczewski et al. (2008) $73.7 \%$ and Patrick et al. (2013) reported the shape index value as $73.97 \%$ in Lavender (Lavender) genotype, $74.77 \%$ in Purple genotype (Royal Purple) and $73.62 \%$ in White (White) genotype in the study conducted by guinea pigs of different genotypes. The findings of this study were similar to our research findings. However, the average shape index value obtained in our study was found lower than Dudusola (2010) (79.57\%), Ivanova et al. (2020) (2016: 76.32\%, 2017: 76.54\%, 2018: 77.96\%), Obike et al. (2014) (Pearl x Pearl: 78.93\%, Black x Black: 77.45\%, Pearl x Black: 76.70\%), Alkan et al. (2013) (76.60\%) and Eleroğlu et al. (2016) (78.18\%).

In our study, the average number of pores-1, number of pores- 2 and number of pores- 3 was $6686.05,5156.10$ and 5043.33, respectively; pore density-1, pore density-2 and pore density- 3 were found to be $120.22,92.62$ and 90.52 pores $/ \mathrm{cm}^{2}$, respectively. In the study conducted by Eleroğlu and Bircan (2019a) to determine the internal and external quality characteristics of guinea fowl eggs with the same methods, the average number of pores-1, number of pores- 2 and number of pores-3 was $6666.25,5132.39$ and 5011.12, respectively; pore density-1, pore density-2 and pore density-3 were found to be 120.32, 92.56 and 90.31 pores $/ \mathrm{cm}^{2}$, respectively, and the results were similar to our study.

Egg surface area was determined as $55.65 \mathrm{~cm}^{2}\left(\min =46.05-\max =63.59 \mathrm{~cm}^{2}\right)$ and egg volume was determined as average $40.39 \mathrm{~cm}^{3}\left(\min =30.34-\max =49.33 \mathrm{~cm}^{3}\right)$.

The obtained values were reported by Alkan et al. (2013) $\left(55.69 \mathrm{~cm}^{2}-38.21 \mathrm{~cm}^{3}\right)$, Wilkanowska and Kokoszyński (2010) (Pearl=54.84 cm2), Bernacki et al. (2013) (Grey=56.3 $\mathrm{cm} 2$, White $=56.2 \mathrm{~cm}^{2}$ ), Patrick et al. (2013) (White $=57.06 \mathrm{~cm}^{2}, 40.87 \mathrm{~cm}^{3}$ ) and Eleroğlu and Bircan (2019a) (55.43 cm2-40.14 $\left.\mathrm{cm}^{3}\right)$ were similar to our results; but Dudusola (2010) $\left(73.13 \mathrm{~cm}^{2}\right.$ ), Patrick et al. (2013) (Lavender $=60.98 \mathrm{~cm}^{2}, 44.38 \mathrm{~cm}^{3}$, Royal Purple $=62.44 \mathrm{~cm}^{2}$, $47.05 \mathrm{~cm}^{3}$, Pearly grey=60.24 $\mathrm{cm} 2,45.84 \mathrm{~cm}^{3}$ ), Wilkanowska and Kokoszyński (2010) (White $=61.40 \mathrm{~cm}^{2}$ ) were lower than our results. 
In the study, average shell thickness, shell weight and shell ratio were found to be $0.28 \mathrm{~mm}$, $3.19 \mathrm{~g}$ and $7.95 \%$, respectively. These values were found to be similar to the study of Eleroğlu and Bircan (2019a) to determine the egg quality characteristics of guinea fowl with the same method, but lower than the other studies conducted to determine egg quality characteristics by measuring method. Eleroğlu and Bircan (2019a) reported average shell thickness, shell weight and shell ratio as $0.28 \mathrm{~mm}, 3.17 \mathrm{~g}$ and $7.95 \%$, respectively. These values were reported as $0.50 \mathrm{~mm}, 6.23 \mathrm{~g}$ and $15.32 \%$; $0.55 \mathrm{~mm}$ by Vekic et al. (2019), $0.55 \mathrm{~mm}, 8.25 \mathrm{~g}$ and $20.18 \%$ by Song et al., (2000), $0.4628 \mathrm{~mm}, 6.31 \mathrm{~g}$ and $13.5 \%$ by Niclova (2009).

Egg core quality characteristics, yolk weight and ratio $6.02 \mathrm{~g}$ and $14.94 \%$; The white weight and ratio were found to be $30.89 \mathrm{~g}$ and $77.11 \%$. Eleroğlu and Bircan (2019a) determined the weight and rate of yellow as $5.95 \mathrm{~g}$ and $14.85 \%$ in guinea fowls; white weight and rate of $30.75 \mathrm{~g}$ and reported as $77.21 \%$. The results obtained in our study were similar to the findings of this study, which was carried out to determine egg quality characteristics with the same method. However, the results obtained from our study, which were compared with the literature, were lower than other research values in terms of yellow weight and ratio (Vekic et al., (2019) (12.55 g and 30.94\%), Niclova (2009) ( $11.84 \mathrm{~g}$ and 29.29\%), Alkan et al. (2013) (13.58 $\mathrm{g}$ and 33.81\%), Dudusola (2010) (14.26 g and 30.6\%) ); It is high in white weight and ratio value (Vekic et al. (2019) (21.84 g and 53.75\%), Niclova (2009) (20.79 g and 51.34\%), Alkan et al. (2013) (21.62 g 50.03\%), Dudusola (2010) ( $26.08 \mathrm{~g}$ and 55.9\% ) was determined. H.E. BEGLI ET AL. (2010) reported the weight of yellow as $12.91 \mathrm{~g}$ and the weight of white as $22.66 \mathrm{~g}$.

As a result, in this study, it was aimed to determine the egg internal and external quality characteristics of guinea fowl by using mathematical formulas based on egg weight without spoiling the egg integrity. The results obtained were similar to those of the studies carried out to determine the internal and external quality characteristics of guinea fowl eggs, but were different in terms of some characteristics with the other study values carried out to determine the egg quality of guinea fowl with the measurement method. While yellow weight, peel weight and peel thickness values were found to be lower than the values determined by measurement, the white weight value was found to be high.

\section{Acknowledgements}

We would like to thank Mr. Kemal KÜTÜK for his assistance in providing guinea fowl eggs.

\section{References}

Akpınar, G.Ç., Alaşahan, S., Doğan, S.C. 2017. "Halk Elinde Yetiştirilen Pekin Ördeklerinde Matematiksel Formüller İle Yumurta Kalite Özelliklerinin Belirlenmesi”, Türk Tarım - Gıda Bilim ve Teknoloji Dergisi, 5(12), 1470 - 1475.

Alkan, S., Karsli, T., Galiç, A., Karabağ, K. 2013. "Determination of phenotypic correlations between internal and external quality traits of Guinea fowl eggs", Kafkas Üniversitesi Veteriner Fakültesi Dergisi, 19(5): 861-867. 
Austin, O.L., Singer A., Zim H.S. 1975. "Birds of the World. A survey of the twenty-seven orders an one hundred and fifty-five families”, New York: Hamilyn; pp. 105-32

Begli, H.E., Zerehdaran, S., Hassani, S., Abbasi, MA., KhanAhmadi, A.R. 2010. "Heritability, genetic and phenotypic correlations of egg quality traits in Iranian native fowl", British Poultry Science, 51:6, 740-744. https://doi.org/10.1080/00071668.2010.528750

Bernacki, Z., Kokoszynski, D., Bawej, M. 2013. "Laying performance, egg quality and hatching results in two guinea fowl genotypes", Arch.Geflügelk., 77(2): 109-115.

Demirsoy, A. (1992). "Yaşamın Temel Kuralları, Omurgalılar (Sürüngenler, Kuşlar ve Memeliler)”, Birinci Baskı, Ankara: Meteksan A.Ş.; cilt 3;s. 279-82.

Dudusolo, I.O. 2010. "Comparative evaluation of internal and external qualities of eggs from quail and guinea fowl”, International Research Journal of Plant Science, 1:112-115.

Eleroğlu, H., Yıldırım, A., Duman, M., Okur, N. 2016. "Effect Of Eggshell Color On The Egg Characteristics And Hatchability Of Guınea Fowl (Numida Meleagris) Eggs", Brazilian Journal of Poultry Science Revista Brasileira de Ciência Avícola ISSN 1516-635X Jul - Sept 2016 / Special Issue Quails / 061-068 http://dx.doi.org/10.1590/1806-9061-2015-0154

Eleroğlu, H., Bircan, H. 2019a. "Beç Tavuklarında (Numida Meleagris) Matematiksel Formüller Kullanılarak Yumurta Kalite Özelliklerinin Belirlenmesi”, 4th International Anatolian Agriculture, Food, Environment And Biology Congress-2019.

Eleroğlu, H., Bircan, H. 2019b. "Beç Tavuklarında (Numida meleagris) Sayısal Görüntü Analizi Kullanılarak Yumurta Kalite Özelliklerinin Belirlenmesi”, 4th International Anatolian Agriculture, Food, Environment and Biology Congress-2019.

Gholipour, V., Chamani, M., Shahryar, H.A., Sadeghi, A., Afshar, M.A. 2017. "Effects of dietary Lglutamine supplement on performance,egg quality, fertility and some blood biochemical parameters in Guinea fowls (Numida meleagris)", Kafkas University Veterinary Fak. Derg. 2017;23(6):903-910.

Hoyt, D.F., Board, R.G., Rahn, H., Paganelli, C.V. 1979. "The eggs of the Anatidae: Conductance, pore structure and metabolism”, Physiological Zoology, 52(4): 438-450.

Ivanova, R., Nikolova, M.. Veleva, P. 2020. "Study on Egg Productivity of Guinea-Fowls (Numida meleagris)", Iranian Journal of Applied Animal Science; (2020), 10(4), 727-734

Koch, T., Rossa, E. 1973. "Anatomy of the Chicken and Domestic Birds", The Iowa State University press, Iowa, 1973; pp. 234-56. 
Nikolova, M., 2009. "Investıgatıon On Some Main Reproductıve Characterıstıcs Of Guinea Fowls (Numida Meleagris)", January 2009. Agricultural Sciences; 1(2):55-59 https://doi.org/10.22620/agrisci.2009.02.009

Nowaczewski, S., Witkiewicz, K., Fratczak, M., Kontecka, H., Rutkowski, A., Krystianiak, S. Rosiñski, A. 2008. "Egg quality from domestic and French guinea fowl”, Nauka Przyr. Technol. 2(2):1-9.

Nwagu, B.I. 1997. "Factors affecting fertility and hatchability of guinea fowl eggs in Nigeria", World Poultry Science Journal. 53:279-285.

Obike, O.M, Oke, U.K, Azu, K.E. 2011. "Comparison of egg production performance and egg quality traits of Pearl and Black strains of Guinea fowl in a humid rain-forest zone of Nigeria", International Journal of Poultry Science, 10:547-551.

Obike, O.M., Nwachukwu, E.N. Aralu, S.N. 2014. "Effect of genotype on egg quality characteristics of guinea fowl (Numida meleagris galeata) in a humid tropical environment", Nigerian Agricultural Journal, Vol. 45 No. 1,103-107.

Oke UK, Herbert U, Nwachukwu EN. 2004. "Association between body weight and some egg production traits in the Guinea fowl (Numida meleagris galeata pallas)", Livestock Research Rural Development, 16:9.

Paganelli C., Olszowka A., Ar A. 1974. "The Avian Egg: Surface Area, Volume And Density", The Condor 102, 193-197.

Patrick, M.K., Lesego, B., Shalaulane, J.N. 2013. "Egg Quality Characteristics of Different Varieties of Domesticated Helmeted Guinea Fowl (Numida meleagris)", International Journal of Poultry Science, 12(4): 245-250

Petek, M. 2004. "Bilinmeyen Bir Ürün: Beç Tavuğu”, Uludağ Üniversitesi Vet. Fak. Derg., 23 (1-2-3):127-129.

Rahn, H., Ar, A. 1980. "Gas exchange of the avian egg: Time, structure and function", American Zoologist, 20(2): 477- 484.

Rahn, H., Paganelli, C.V. 1988. "Length, Breadth, and Elongation of Avian Eggs from the Tables of Schönwetter”, Journal für Ornithologie, 129(3): 366-369.

Rahn, H., Paganelli, C.V. 1989. "Shell mass, thickness and density of avian eggs derived from the tables of Schönwetter", Journal fur Ornithologie, 130: 59-68.

Rahn, H., Paganelli, C.V. 1990. "Gas fluxes in avian eggs: Driving forces and the pathway for exchange”, Comparative biochemistry and physiology part A: 95(1): 1-15. 
Sarıca, M., Erensayın, C. (2009). “Tavukçuluk ürünleri. Tavukçuluk Bilimi, Yetiştirme, Besleme, Hastalıklar”, (Ed. M.Türkoğlu, M. Sarıca) Bey Ofset Matbaacılık, 3. Basım, s., 588.

Singh, C.B., Kumar, D. 2008. "Genetic parameters of production traits of native fowl of Garhwal Himalayas”, Indian Journal of Poultry Science, Volume : 43, Issue : 3 Page : ( 361362).

Smith, A.J. 1990. "The tropical agriculturist: Poultry", Mcmillan, London and Basingstoke. $218 \mathrm{p}$.

Song, K.T., Choi, S.H., Oh, H.R. 2000. "A comporison of egg quality of pheasant, chukar, quail and Guinea fowl”, Asian-Australian Journal of Animal Science, 13 (7): 986-990.

Sotherland, P.R., Rahn, H. 1987. "On the composition of bird eggs”, The Condor,89: 48-65

Tebesi, T., Madibela, O.R., Moreki, J.C. 2012. "Effect of storage time on internal and external characteristics of Guinea fowl (Numida meleagris) eggs", Journal of Animal Science Advance, 2 (6): 534-542.

Vekić, M., Savić. D., Cvijanović., D. 2019. Changes of Selected Egg Quality Traits Depending on the Laying Period of Semi-Intensively Raised Guinea Fowl Hens. Agroknowledge Journal, Vol. 20, No. 3, 141-149

Yamak, U.S., Boz, M.A., Sarıca, M. 2015. "Changes in guinea fowl fertility and hatching traits over a 4-month laying season with long-term egg storage conditions", Indian Journal of Animal Research, 49 (4) 2015 : 532-536.

Wilkanowska, A., Kokoszynski, D. 2010. "Comparison of morphological composition and interior quality of eggs from pearl and white guinea fowl (in Polish)", Acta Sci. Pol., Zootech. 9(1): 47-54. 